
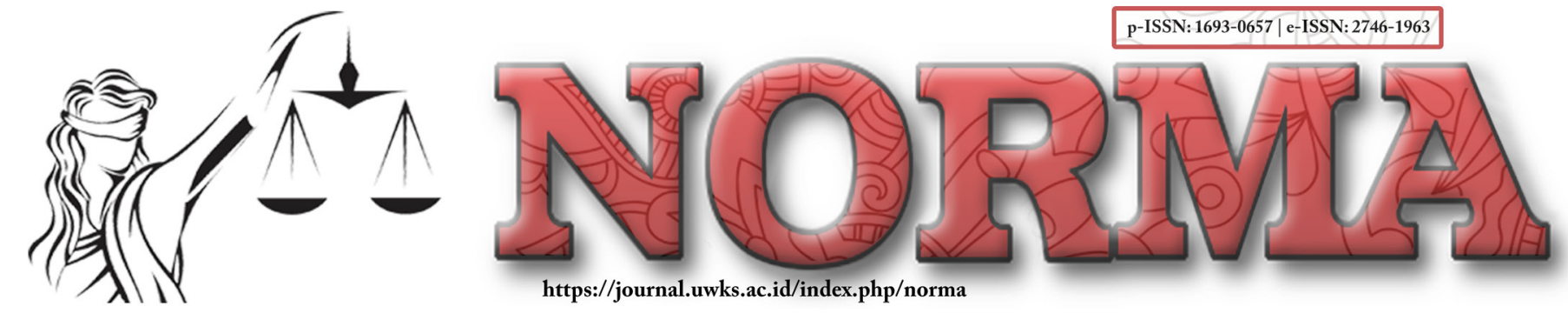

\title{
Pandemic as Reasons to Avoid Pre-Project Selling Default: Law Refinement to Provide Justice and Supports Business Activities in Covid19 Era
}

\author{
Fani Martiawan Kumara Putra; Shanti Wulandari \\ Universitas Wijaya Kusuma Surabaya \\ e-Mail: fanimartiawan@gmail.com; shanti.zne@gmail.com
}

\begin{abstract}
:
The study, Pandemic as Reasons for Debtors to Avoid Default: Law Refinement to Provide Justice and Supports Business Activities in Covid19 Era, aims to find out and analyze the problems of default that occurred during this Covid19 pandemic, especially in the Pre-Project Selling event. Failure to make achievements can occur not only because of economic constraints, but also because of limited tools and personnel during the pandemic. This means that failure to make achievements is not only on the developer's side, it can also be from the buyer's side, while the disputes that occur are not those that have a low nominal, therefore cases often end up in court. This is a normative research with a statutory approach. The results obtained from this study are that the judge who decides the case can at least provide a legal smoothing on the state of default during this Pandemic, so that justice can be realized and will also support business activities.
\end{abstract}

Keywords: Pre-Project Selling; Pandemic; Default.

\author{
Article's History: \\ Received: \\ April 20, 2021; \\ Peer-Reviewed: \\ June 21, 2021; \\ Accepted: \\ July 15, 2021; \\ Published: \\ July 30, 2021. \\ DOI:
}

10.30742/nlj.v18i2.1591

\section{INTRODUCTION}

Humans are related to each other reciprocally which can also lead to a legal relationship. Legal relationship is a relationship between one party and another party that causes legal consequences, including trade.

Problems that are often faced in relation to housing development, especially in urban areas, are caused by population growth that continues to increase, while land supplies are very limited. The price of land is quite high and the location of the land is not possible where it is needed to build houses in large numbers using relatively small land. The situation as mentioned above, at this time also began to develop residential development with a housing system. This is based on the idea of efficient use of the land needed to build the residence, by using a system of more than one floor, and it is necessary because it is a good housing business strategy.

The more widespread development at this time, followed by the increasing number of business actors engaged in the housing sector. Developers or developers are business actors who provide residential units, whether in the form of one house or like 
an apartment. The more people who need houses, the more residential units that must be offered to consumers, inevitably this situation forces the marketing department or property agents to actively offer these residential units that will be or have been built. As a consequence of the increasingly competitive free market, various marketing strategies continue to be developed and implemented, all of which are done so that all residential units that have been built or sold quickly for additional capital for developers, the investment value invested will return immediately and are expected to immediately get a profit.

The marketing strategy that is currently often applied by developers, or residential property agents, is to offer residential unit sales with a "pre project selling" sales pattern or strategy, namely sales made before the property development project begins. This strategy is by offering residential units of flats/apartments or housing through various property exhibitions, either individually or collectively, to consumers, by showing pictures or brochures of designs for future residential forms, while the physical buildings offered by the developer are currently or even not built yet.

Not all sales with the pre-project selling method run smoothly, there are often obstacles, namely delays in development, or incompatibility with what is being offered, delays in the process of transferring land rights, and even criminal events. Currently, the potential for the buying and selling process to run smoothly with preproject selling is getting bigger. In fact, in the field, there have been several reports of the failure of developers in realizing housing that is sold using the pre-project selling method. This is due to the impact of the Covid19 Pandemic, which is not only about the developer economy, but also the availability of workers, as well as other things.

The pandemic that is happening in Indonesia and in other countries at this time is the corona virus disease 2019 (hereinafter referred to as Covid-19) where the Covid-19 pandemic has been determined by Presidential Decree of the Republic Indonesia number 12 of 2020 concerning the determination of non-natural disasters spreading corona virus disease 2019 (Covid-19) as a national disaster. The presidential decree stated that non-natural disasters caused by the spread of Covid-19 have an impact on increasing the number of victims and property losses as well as having implications for broad socio-economic aspects in Indonesia. The World Health Organization (WHO) has declared Covid-19 as a global pandemic on March 11, 2020. This Covid-19 pandemic has hit almost the entire world to date and is growing quite rapidly in transmission. The COVID-19 pandemic has had a tremendous impact on human life, namely the impact on health that is very serious and can cause death, in addition to the health impact it also has an impact on the economy of the entire country.

The economic impacts include delays in the production process, due to the increasing scarcity of raw materials, especially those originating from imports, which were stopped, the cessation of the tourism, entertainment and hospitality and aviation 
industries due to social restrictions and regional closures, as a result of which there were many reductions in employees which led to temporary layoffs of employees, there are even layoffs (hereinafter referred to as layoffs) so that it can lead to a decrease in income and an increase in unemployment as well as an increase in crime.

Of course, with a situation like this, there will be parties who are harmed, be it the developer, or the buyer. Of course, with a nominal that is not small, then of course the settlement is often carried out until the trial. The judge, in this case, is demanded for his wisdom in deciding such cases fairly, and the authority of his decision can support similar business activities with similar problems.

\section{RESEARCH METHOD}

This research is a normative legal research with statutory approach.

\section{DISCUSSION}

Default will not exist without Achievement, which achievement is the object of the law of engagement. Engagement law is a law that regulates legal relations between legal subjects with one another in the field of civil law (property law where one party has the right to an achievement (creditor) and the other party is obliged to provide achievements (debtor). There are elements of engagement law including:

Legal relationship. The purpose of the legal relationship here is the bond between the parties which is intended to give birth to legal consequences, matters and obligations arising from the relationship are regulated by law. In carrying out the obligations in the engagement, legal assistance may be requested if necessary.

Legal subject. The legal subject can be in the form of a creditor, which means that the creditor is the party entitled to the achievement. The creditor can be said to be an active party because the creditor has the right to the debtor's achievements and the creditor can take certain actions against the debtor who does not want to fulfill his obligations, in terms of assets in legal subjects, namely creditors, there are material rights to achievements and the authority to realize these rights. through a lawsuit. The legal subject can also be a debtor, which means that the debtor is the party who is obliged to provide achievements, the debtor can also be said to be a passive party because he has an obligation to provide achievements.

Civilization (wealth). In civil law, according to legal science, the first regulates people, the second regulates family, the third regulates assets, the fourth regulates inheritance, while according to BW, book I regulates people; book II regulates objects; book III regulates engagement; book IV regulates evidence and expiration. Which is where the law governing assets is contained in Books II and III BW. This means that in the engagement there is a legal relationship that gives rise to rights and obligations that have economic value/money value. In other words, if the debtor's obligations are 
not fulfilled, the creditor can get compensation in the form of a certain amount of money.

Achievements. Achievements according to Article 1234 BW are giving something, doing something, and not doing something.

The law of engagement as regulated in Book III BW (Article 1233-1864) is still valid today, because there is still no new law regarding the law of engagement. CHAPTER I-IV, regulates the general provisions of the engagement in Articles 1352 and $1354 \mathrm{BW}$. Article $1235 \mathrm{BW}$ states that in every agreement to give something, it is contained in the obligation of the debtor to surrender the object in question and to take care of it as a good housewife, until the time of delivery. This article describes a consensual agreement (which was born at the time of reaching an agreement) whose object is goods, where from the moment the agreement is reached, the person who is supposed to deliver the goods must continue to take good care of the goods as it is appropriate to maintain their own property as well as take care of his other belongings, which will not be handed over to others. The obligation to take good care lasts until the item is handed over to the person who must receive it. Or it can be interpreted by surrendering into the ownership of others to be enjoyed or controlled by others. For example, if A buys a motorbike from B, then A has to pay money to B for the price of the motorbike (gives something with money), and $\mathrm{B}$ gives the motorbike to $\mathrm{A}$ (gives something with a motorbike). ${ }^{1}$

Doing something in an engagement which is always related to legal subjects, not legal objects. That is, it means to do the act as stipulated in the engagement. So the form of achievement here is to do certain actions. In carrying out this achievement the debtor must comply with what has been determined in the engagement. The debtor is responsible for his actions that are not in accordance with the provisions agreed upon by the parties. However, if these provisions are not agreed upon, then herein applies the appropriateness or appropriateness measure that is recognized and applies in the community. This means that one should act as a good worker. In this case, every positive achievement that is not in the form of giving something and is usually related to a certain profession, for example, if someone A is a motorcycle buyer and B is a motorcycle seller, where one time A bought a motorcycle at shop B for 15,000,000. A and $\mathrm{B}$ have an agreement where $\mathrm{A}$ will buy a motorbike with a motorbike price of $15,000,000$ then $B$ will deliver the motorbike to A's house. The next day A pays the motorbike to B for 15,000,000 and B delivers the motorbike to A. ${ }^{2}$

The commitment not to do something is still a form of achievement and must be fulfilled. The party concerned is burdened with a prohibition to perform a certain legal act. If the person concerned as the debtor is prohibited from taking certain legal actions

\footnotetext{
1 Moch. Isnaeni, Hukum Perikatan (Surabaya: Revka Petra Media, 2017), 155.

2 Ibid., 181.
} 
so that the other party (creditor) does not suffer losses. In other words, for the creditor it is the right to demand that something not be done or to prohibit others from doing something, while for the debtor it is an obligation not to do something. From this statement we can take an example, namely if someone $\mathrm{A}$ is a motorcycle buyer and a $\mathrm{B}$ is a motorcycle seller, where one time A bought a motorcycle at B shop for 15,000,000. $A$ and $B$ have an agreement in which A will buy a motorbike with a motorbike price of 15,000,000 then B will deliver the motorbike to A's house. The next day A has paid the motorbike to B for $15,000,000$ but $B$ has not sent the motorbike to $A .^{3}$

The object of the engagement is the achievement as described above (giving something, doing something, not doing something). Debtors in providing their achievements have the following conditions of achievement:

1. The object of the engagement (achievement) must be certain or can be determined (Article 1320 sub $3 \mathrm{BW}$ );

2. The object of the engagement must be permitted (according to Article $1337 \mathrm{BW}$ ). Will not cause an engagement if the object is contrary to decency, public order or prohibited by law;

3. There is no achievement requirement that it should be possible to fulfill; Subjectively impossible (In this case, the debtor may not fulfill his obligations, for example, a paralyzed person is ordered to drive. The engagement can be null and void). Objectively impossible (In this case the object of the engagement is impossible to fulfill, for example, someone is ordered to take the planet Pluto).

Default is an abbreviation of wan which means disability and achievement (giving something, doing something or not doing something). Default can also be referred to as an achievement that is not given by someone who has an obligation to provide his achievements. The legal basis for default is contained in a contrario of Article $1234 \mathrm{BW}$, therefore default is not giving something, not doing something, doing something that is prohibited, being late in fulfilling something which has been agreed.

As explained that the achievement must be fulfilled by the debtor but a reasonable grace period is needed with an agreement that includes a deadline for achievement if the agreement does not include a performance deadline then the default does not occur by law, but in its development there is a time limit for the achievement of the agreement as well. may not necessarily bring the debtor into a state of default. Another important element is the granting of a subpoena to the debtor and all depends on the type or content of the agreement itself. Summons are divided into 2, namely:

1. Summons are given at least two (2) times because if the first summons does not reach the person concerned and when the summons has been given twice there is no response at all, legal action can be taken;

2. In accordance with the decision of the Supreme Court of the Supreme Court

\footnotetext{
${ }^{3}$ Ibid., 184.
} 
No. $852 / \mathrm{K} / \mathrm{Sip} / 1972$, the subpoena is only given one (1) time, if it can be filed in court, then the court issues a summons which according to the Supreme Court is already a subpoena.

The subpoena can be used if: ${ }^{4}$

1. The debtor does not fulfill the performance at all. This means that the debtor does not fulfill the obligations that have been agreed upon by the other party to fulfill his obligations in an agreement or does not fulfill his obligations that have been stipulated by law in the engagement. The debtor does not fulfill his performance, it can be said that the debtor did not give something or did nothing;

2.' The debtor fulfills his performance but does not comply with the agreement. This means that the debtor carries out or fulfills his obligations that have been agreed upon by other parties in accordance with the law, but what is given by the debtor is not appropriate according to the quality specified in the agreement;

3. Debtors are not punctual or late in fulfilling achievements. This means that in the agreement a time, place and price has been stipulated, but the debtor carries out his obligations and fulfills his achievements late or exceeding the time limit set by the parties in the agreement, a statement is needed stating that the debtor is negligent / subpoena. If a subpoena has been issued, the debtor can be charged with compensation.

There are several circumstances that do not require a negligent statement or subpoena, including:

1. If the agreement is specified;

2. The debtor refuses to fulfill;

3. The debtor admits that he was negligent;

4. Fulfillment of achievements is impossible;

5. Fulfillment of achievement no longer matters;

6. The debtor does not fulfill the performance as it should.

As it has been understood that default is essentially an act committed by the debtor in the form of not performing as an obligation, so that the creditor does not get his rights and that is clearly a loss. Default itself can be caused by two things, namely:

1. This type of default that is carried out intentionally is still divided into two types, namely: (a). Totally on purpose; (b). Default due to negligence.

2. Default due to overmacht or force majeure.

Regarding the intentional default, the legislators have arranged it coherently and clearly, where the form of achievement is stipulated in Article 1234 BW and that achievement must be fulfilled as confirmed by Article $1235 \mathrm{BW}$. With a default, it means that performance as an obligation was not fulfilled and this is clearly a wrong

${ }^{4}$ Ibid., 207. 
act. According to Indonesian law, whoever is at fault must take the risk, then the risk must be borne by the wrong party, namely the debtor who has defaulted. The risk is explained by Article $1236 \mathrm{BW}$ which is obliged to pay compensation, fees and interest. ${ }^{5}$

This can also be seen from the stipulation of Article $1243 \mathrm{BW}$ which confirms that reimbursement of costs, losses and interest due to non-fulfillment of an engagement, then becomes obligatory if the debtor after being declared negligent in fulfilling his engagement, continues to neglect it or if something that must be given or a grace period is made. which has been exceeded, which in that article determines that the reimbursement of costs, losses and interest by the debtor can only be made, after the debtor declares negligence because it does not fulfill the contents of the engagement. In an agreement either to surrender or to do something has been determined with a time limit, then with the passing of the time limit for fulfilling obligations for the debtor, the debtor can immediately be said to be in default, because the passing of the grace period to fulfill the obligations of a debtor is considered negligent to fulfill his achievements. As for what is meant by negligent in the provisions of Article $1238 \mathrm{BW}$, it is determined that: "The debtor is negligent, if he has been declared negligent by a warrant or with a similar deed, or for the sake of his own engagement stipulates that the debtor will continue to be considered negligent with the passage of time. which have been specified".

If a debtor has been warned by the creditor or has been expressly billed for his promise, as explained above, then if he still does not carry out his achievements, then the debtor can be said to be in a state of default and against him he can be treated with juridical sanctions as a legal consequence thereof.

In general, many people think that default is part of an unlawful act (genus specific). This assumption seems to be true at first glance, but when it is to be written down in the form of a written claim, it is not permissible to mix the two together because it will lead to errors which in the end will obscure the purpose of the lawsuit itself. There are some very principal differences between default and unlawful acts. The principal difference is: ${ }^{6}$

\section{Source}

1. Default arises from agreement. This means that in order to postulate that a legal subject has defaulted, there must first be an agreement between the two parties as stipulated in Article 1320 BW;

2. Acts against the law are born because the law itself determines. This is as referred to in Article 1352 BW.

\section{The emergence of the right to sue}

1. In default, a process is required, such as a statement of negligence (inmorastelling,

\footnotetext{
5 Ibid., 208.

${ }^{6}$ Wiryono Prodjodikoro, Perbuatan Melanggar Hukum (Bandung: Sumur, 1992), 53.
} 
negligent of expression, interpellatio, ingeberkestelling). This is as referred to in Article $1243 \mathrm{BW}$ which confirms that the engagement is intended to give something, to do something, or not to do something, or if it turns out that in the agreement there is a clause that says the debtor is immediately deemed negligent without requiring a summons or warning;

2. This is reinforced by the jurisprudence of the Supreme Court No. 186 K/Sip/1959 dated July 1, 1959 which states that if the agreement explicitly determines when the fulfillment of the agreement, according to law, the debtor cannot be said to have failed to fulfill his obligations before it is stated to him in writing by the creditor;

3. In an unlawful act, the right to sue can be carried out without the need for a subpoena. Once an unlawful act arises, at that time the injured party can directly sue it (action, claim, rechtvordering).

\section{Claims for compensation (compensation, indemnification).}

1. In default, the calculation of compensation is calculated from the time the negligence occurred;

2. This is as stipulated in Article $1237 \mathrm{BW}$, regarding the cost of compensation itself is regulated in Article 1246 BW.

Starting from the opinion above, regarding unlawful acts, legal rights and obligations must be considered based on the law (wet), so the act must actually violate the rights of others or be contrary to its own legal obligations given by law. Thus, breaking the law is the same as breaking the law. ${ }^{7}$

Based on this study, if it is related to buying and selling using the pre project selling system, whether its position is only as an order agreement, or it has been tied to PPJB, then if one of the parties, be it the developer or the buyer, is in default, a claim can be submitted to the court, because the claim is in a civil case, then the party who defaults can be held accountable in the form of compensation.

This claim must be a claim for default, it must not be a lawsuit for violating the law, because this is based on an agreement between the parties, not an order agreement or PPJB, but an agreement between the buyer and the developer when there is an agreement and fulfills the principle of consensualism.

Agreement is defined as a legal relationship between two or more parties based on an agreement to cause legal consequences. So according to not only see the agreement solely, but must be seen previous actions or actions that preceded it. These actions include:

1. The stage before the agreement, namely the existence of an offer and acceptance;

2. The agreement stage, namely the adjustment of the statement of will between the parties and the stage of implementing the agreement. This means that

7 Abdul Kadir Muhammad, Hukum Perikatan (Bandung: Citra Aditya Bakti, 1990), 144. 
the principle of consensualism has been fulfilled in this agreement, and the emergence of legal consequences (growth/disappearance of rights and obligations).

This principle of consensualism is in accordance with Article 1458 BW which stipulates that buying and selling has occurred between the two parties immediately after they have reached an agreement on the goods and the price even though the goods have not been delivered and the price has not been paid.

Sometimes achievements cannot be made or are hindered due to a certain thing, this can be in the form of natural disasters and so on. As at this time, many countries have been affected by COVID-19, one of which is Indonesia. Covid-19 has a very fast transmission rate, the higher the risk of death for someone with a weak immune system, meanwhile the anti-virus that has not been found has forced a number of countries and governments to take policies that have legal implications. This policy is a lockdown or social distancing policy, an example of a lockdown or social distancing activity, namely maintaining a distance between people.

This has disturbed many business people, many companies or people who cannot keep their promises or cannot carry out their obligations. In other words, many contracts, agreements, business transactions or activities have been delayed due to the spread of the COVID-19 outbreak. In a covid-19 pandemic like this, many companies are reducing their workers or laying off workers in order to fulfill the call from the president, which is absolute, to reduce crowds in one place in order to minimize someone who is infected with the covid-19 virus or can reduce the existing virus. In conditions like this, it adds to the burden of many workers who have been laid off, because the workers who have been laid off have dependents to pay for credit for the goods, they have purchased from creditors prior to the COVID-19 pandemic.

In this situation, a dispute that has entered the realm of the Court, then of course one of the parties can easily enter a state of default as long as a subpoena has been given, or there is no need to be given a summons but it has been confirmed when the last time is. Judges can actually easily give a decision on the basis of the considerations and the theory of default above.

However, in order to support business activities, and the realization of justice for the changing reality of the situation, the Judge must of course make legal refinements. Legal refinement in Dutch is called rechtsverfijning, which comes from lema fijn which means smooth. Prof. Sudikno Mertokusumo prefers the term legal narrowing. Legal narrowing is not an argument to justify the formulation of laws and regulations. If it is not formulated subtly, then the formulation in the legislation is too broad. ${ }^{8}$

Legal refinement is often seen as the opposite of analogy. According to its purpose, the law must not settle a case unfairly or not according to social reality.

${ }^{8}$ Sudikno Mertokusumo, Penemuan Hukum: Sebuah Pengantar, 4th ed. (Yogyakarta: Liberty, 2006), 71. 
However, sometimes judges cannot apply a written provision because if it is applied it will cause injustice. In this case, the judge is forced to remove the case from the regulatory environment, and then settle the case according to the rules that he made himself. The act of issuing that is what Utrecht calls legal refinement. ${ }^{9}$

Refinement or narrowing of the law is needed because often the scope or scope formulated in the legislation is too broad. Judges need efforts to narrow the scope so that it can be applied to concrete events. Utrecht called the legal refinement 'perfecting the legal system' or 'intending to fill an empty space in the statutory system'10

Mochtar Kusumaatmadja and B. Arief Sidharta stated that legal refinement is carried out if the application of written law as it is will result in extreme injustice so that written legal provisions should not be applied or applied differently if justice is to be achieved. ${ }^{11}$

For example, based on jurisprudence (Supreme Court Decision No. 639K/ Sip/1972 dated February 26, 1973) then one of the heirs can file a lawsuit to ask for his share of the inheritance. This means that the heir must ask for the determination of the heir and the determination that the disputed property is an inheritance that has not been divided. At present the closed nature of a village can be said to no longer exist because of the influence of wandering life. Many of the original inhabitants of a village have moved to other places to earn a living with the result that families often break up so that it is no longer known where each of them is located. This state of modern society raises the need for a rechtsverfijning that allows legal protection to maintain the integrity of the inheritance". ${ }^{12}$

Based on the description above, it can be understood that in this case the judge can refine the law by adjusting to the current pandemic situation, for some cases of default in which the fulfillment of achievements is basically hampered due to the pandemic and the limited space for movement due to government regulations, the pandemic situation can be used to dismissed the claim of default. However, not all default situations can be countered by postulating a pandemic. This is where the judge's authority and wisdom are needed.

\section{CLOSING}

\section{Conclusion}

Property sales based on the Pre-Project Selling method are very popular and widespread, therefore even during the Covid19 pandemic, this activity is still rampant, but even before the pandemic period this activity often encountered problems which

${ }^{9}$ E. Utrecht and Moh. Saleh Djindang, Pengantar Dalam Hukum Hukum Indonesia, 10th ed. (Jakarta: Ichtiar Baru, 1983), 223.

${ }^{10}$ Ibid.

${ }^{11}$ Mochtar Kusumaatmadja and B. Arief Sidharta, Pengantar IImu Hukum, Suatu Pengenalan Pertama Ruang Lingkup Berlakunya Ilmu Hukum (Bandung: Alumni, 2000), 119.

${ }^{12}$ Chaidir Ali, Yurisprudensi Hukum Acara Perdata Indonesia, 1st ed. (Yogyakarta: Nur Cahaya, 1999), 131. 
included default events, as well as during the Covid19 pandemic. , the potential for default is greater considering not only the problem of funds, but also the willingness of the workers, as well as some restrictions imposed by the Government. The dispute has a greater potential to be resolved through litigation, therefore the Judge in this case can make legal refinements by adjusting to the current pandemic situation, for some cases of default in which the fulfillment of achievements is basically hampered due to the pandemic and the limited space for movement due to government regulations, the situation is pandemic can be used to dismiss a default lawsuit. However, not all default situations can be countered by postulating a pandemic.

\section{Recommendation}

Preferably in the agreement made by the parties, it has also been emphasized in a clause, regarding certain concessions given to each party carrying out their achievements during this pandemic, so that in this case, the Judge is easier to smooth the law.

\section{REFERENCES}

Abdul Kadir Muhammad. Hukum Perikatan. Bandung: Citra Aditya Bakti, 1990.

Ali, Chaidir. Yurisprudensi Hukum Acara Perdata Indonesia. 1st ed. Yogyakarta: Nur Cahaya, 1999.

Kusumaatmadja, Mochtar, and B. Arief Sidharta. Pengantar Ilmu Hukum, Suatu Pengenalan Pertama Ruang Lingkup Berlakunya Ilmu Hukum. Bandung: Alumni, 2000.

Mertokusumo, Sudikno. Penemuan Hukum: Sebuah Pengantar. 4th ed. Yogyakarta: Liberty, 2006.

Moch. Isnaeni. Hukum Perikatan. Surabaya: Revka Petra Media, 2017.

Prodjodikoro, Wiryono. Perbuatan Melanggar Hukum. Bandung: Sumur, 1992.

Utrecht, E., and Moh. Saleh Djindang. Pengantar Dalam Hukum Hukum Indonesia. 10th ed. Jakarta: Ichtiar Baru, 1983. 